\title{
A convenção das nações unidas para o direito do mar e a instituição do tribunal internacional para o direito do mar*
}

\section{The un convention on law of the sea and the institution of the international tribunal for the law of the sea}

Fernanda Weigert ${ }^{1}$

Rui Aurélio de Lacerda Badaró ${ }^{2}$
* Artigo recebido em 30/09/2011

Aprovado em 28/10/2011

1 Bacharel em Relações Internacionais e Acadêmica de Direito no Centro Universitário Curitiba.

2 Bacharel em Direito pela Universidade Metodista de Piracicaba (2001) e mestrado em Direito pela Universidade Metodista de Piracicaba (2003). Professor da Universidade Federal do Rio Grande do Sul, coordenador-adjunto do curso de direito do Instituto Educacional do Estado de São Paulo e coordenador de pós-graduação lato sensu da Escola Paulista de Direito.

\section{Resumo}

O objetivo deste artigo é apresentar algumas questões relacionadas à instituição do Tribunal Internacional para o Direito do Mar a partir da Convenção de Montego Bay de 1982, mostrando suas principais características e principais métodos de resolução de conflitos. A metodologia utilizada para a realização desta pesquisa foi o uso de conceitos trazidos por autores como Paulo Borba Casella, Adherbal Meira Mattos, Thomas A. Mensah e Tafsir Malick Ndiaye, tomando por base suas formações conceituais e pensamentos acerca das principais atividades do Tribunal, a fim de elaborar uma síntese dos aspectos mais importantes, tanto da Convenção, quanto das suas Regras, fornecendo uma visão geral de conceitos trazidos pela Convenção sobre o Direito do Mar e dos procedimentos adotados para a resolução de conflitos, para então realizar uma crítica a respeito das barreiras impostas aos EstadosPartes para o acesso ao Tribunal.

Palavras-chave: Direito do Mar. Tribunal. Resolução de conflitos.

\begin{abstract}
The main goal of this article is to present some issues related to the institution of the International Tribunal for the Law of the Sea starting from the Montego Bay Convention of 1982, showing its main characteristics and most important conflict resolution methods. The methodology used in this research is the analysis concepts brought by authors like Paulo Borba Casella, Adherbal Meira Mattos, Thomas A. Mensah and Tafsir Malick Ndiaye, taking their thoughts and concepts as grounds for a synthesis on the main subjects involving the Convention and the Tribunal's Rules, such as provide a general view of concepts brought by the Law of the Sea Convention and its conflict resolution procedures to comment the barriers that States have to deal with in order to assess the Tribunal.
\end{abstract}

Keywords: Law of the Sea. Tribunal. Conflict resolutions. 


\section{Introdução}

Após longas rodadas de discussão acerca dos conceitos que a Convenção para o Direito do Mar trataria, foi estabelecida a Convenção de Montego Bay em 10 de dezembro de 1982, denominada a partir desse momento de Convenção, entrando em vigor em 16 de novembro de 1994, depois de obter mais do que a metade das ratificações necessárias para isso.

Ela é composta de um Preâmbulo, 17 partes e 9 anexos, sendo que, no preâmbulo, são tratados os problemas do espaço oceânico, que estão intimamente ligados e devem ser tratados como um todo. É discutido a respeito da soberania estatal e a necessidade da existência de uma ordem jurídica que facilite a comunicação entre os Estados, promovendo o uso pacífico das águas e uma ordem econômica internacional justa. ${ }^{3}$ As 17 partes da Convenção tratam da formação da Plataforma continental, da área, da solução de controvérsias e da participação de organizações internacionais.

Neste trabalho, serão expostas rapidamente as zonas conceituadas pela Convenção, bem como suas características principais, a jurisdição e direitos soberanos dos Estados sobre cada uma delas, como definidos nos termos da Convenção sobre o Direito do Mar, para que o estudo de caso seja mais bem entendido e contextualizado, tendo em vista a vasta utilização desses conceitos.

${ }^{3}$ MATTOS, Adherbal Meira. O novo Direito do Mar. Rio de Janeiro: Renovar, 2008. p. 4.

${ }^{4}$ KEYUAN, Zou. The International Tribunal for the Law of the Sea: Procedures, Practices, and Asian States. Ocean Developmend and International Law, 41,131-151, 2010. p. 132.

\section{Aspectos Gerais da Convenção de Montego Bay de 1982}

A Convenção trata de diversas zonas, definindo para cada uma delas um grau de soberania e jurisdição dos Estados costeiros, bem como protegendo os direitos dos países geograficamente desfavorecidos (aqueles que não possuem saída para o mar). Como o Direito do Mar é uma matéria fundamentalmente consuetudinária, sentiuse a necessidade de positivação desses costumes para a formação de uma responsabilidade estatal, assegurando os direitos dos países geograficamente desfavorecidos e coibindo o uso indiscriminado dos recursos naturais.

O costume é fonte do Direito Internacional, que não é acordado convencionalmente, mas que possui poder e importância tais que pode vir a revogar tratados, sendo essencial para o desenvolvimento do Direito Internacional, principalmente pela falta de uma autoridade central a nível mundial. ${ }^{5}$

\begin{abstract}
A importância dos costumes do Direito Internacional decorre do tradicional baixo nível de codificação normativa entre os Estados. Ainda hoje, a maioria das situações é regulada por práticas tradicionais, sobretudo aquelas consolidadas por decisões judiciais, que se perpetuam ao longo do tempo. Tais práticas adquirem um valor em si e passam a ser consideradas como fonte de direito, com valor suficiente para reprovar as condutas dos Estados, contrárias aos costumes. $^{6}$
\end{abstract}

Apesar do dinamismo da sociedade internacional atual, ele continua sendo capaz de se adaptar às exigências, confirmando sua natureza eminentemente evolutiva. ${ }^{7}$ Também se pode afirmar que, por ser uma prática adotada pelos membros da sociedade internacional, é obrigatória, por ser socialmente necessária, não sendo criada somente pela ação dos Estados, mas também pelas práticas exercidas nas Organizações Internacionais ${ }^{8}$, sendo o direito de veto dos membros do Conselho de Segurança da ONU o maior exemplo disso.

5 MIRANDA, Jorge. Curso de direito internacional público. 3. ed. Estoril: Princípia, 2006. p. 46.

6 VARELLA, Marcelo Dias. Direito internacional público. Brasília: UniCEUB, 2008. p. 124.

7 PEREIRA, André Gonçalves; QUADROS, Fausto de. Manual de direito internacional público. 3. ed. Coimbra: Almedina, 2005. p. 155.

8 MIRANDA, op. cit., p. 47. 
Grande parte das preocupações dos Estados estava voltada à segurança e à proteção das suas rotas comerciais e das regiões costeiras, para que não faltassem alimentos. ${ }^{9}$ Não havia necessidade para a elaboração de normas mais específicas, formando um "vácuo legal" ${ }^{10} \mathrm{e}$, com o pensamento de Grocius em sua obra "Mare Liberum", difundiu-se a ideia de liberdade do mar como uma verdade incontrovertida.

Com o tempo, ficou claro que o Estado costeiro possuía total soberania sobre o mar territorial, mas nenhum costume surgiu com relação à extensão desse mar territorial e grandes potências como os EUA, Grã-Bretanha, Alemanha, França, Japão e outros que adotavam a extensão de três milhas náuticas.

Até hoje há controvérsias com relação à extensão de áreas, como a plataforma continental e o mar territorial, sendo que países como os Estados Unidos da América ainda não ratificaram a Convenção por não acharem necessário e não aceitarem, por exemplo, o estabelecimento da zona econômica exclusiva com a extensão de 200 milhas náuticas (aproximadamente 340 quilômetros), coisa que consideram como sendo uma exigência exacerbada por parte de países em desenvolvimento.

Apesar de a Marinha Americana defender arduamente a ratificação da Convenção pelos Estados Unidos da América, alguns estudiosos acreditam não ser necessário, principalmente por alegarem que o país consegue defender seus interesses por meio do direito costumeiro e o US Freedom of Navigation Program (FON), cujo objetivo é:

\begin{abstract}
Não somente manter o direito de operar livremente dentro e fora das águas internacionais. Os objetivos mais importantes são, primeiramente, fazer com que outras nações reconheçam e respeitem direito de todas as nações de operar, em conformidade com as provisões da Convenção sobre o Direito do Mar, dentro e sobre o mar territorial e, em segundo lugar, minimizar as tentativas de outros Estados de reduzir estes direitos fazendo exigências excessivas. ${ }^{11}$
\end{abstract}

No final da década de 1940, outros países como a Argentina e o Chile reivindicaram o direito de uso sobe-

\footnotetext{
9 ANAND, Ram Prakash. Law of the sea: Caracas and Beyond. Haia: Martinus Nijhoff Publishers, 1980. p. 36.

${ }^{10}$ Ibidem, p. 37.

${ }^{11}$ GROVES, Steven. Accession to the U.N Convention o the Law of the Sea is unecessary to Secure U.S. Navigational Rights and Freedoms. Backgrounder, Washington, The Heritage Foundation, n. 2599, 2011. p. 7.
}

rania de 200 milhas marítimas e, mais tarde, as reivindicações sobre os direitos de uso da plataforma continental continuaram mudando em virtude do contexto político, como por exemplo, a crise dos mísseis cubanos na década de 1960, o que fez surgir a necessidade de estabelecer uma Convenção que tratasse de conceitos e que uniformizasse a largura do mar territorial e suas zonas adjacentes, culminando com a assinatura da Convenção de Montego Bay de 1982. ${ }^{12}$

A Convenção tratou de conceituar e estabelecer extensões para cada uma das áreas antes tratadas costumeiramente, procurando dirimir as controvérsias existentes sobre o Direito do Mar e preenchendo um vácuo legal há muito tempo existente.

\section{1 Águas interiores}

Pela definição de Adherbal Meira Mattos ${ }^{13}$, as águas interiores são aquelas que se encontram aquém da linha de base (a partir do qual o mar territorial é determinado), sendo tidas como águas internas ou nacionais, tendo seu regime jurídico normatizado pelos Estados costeiros, os quais exercem plena soberania tanto sobre elas, quanto ao espaço aéreo acima e seu subsolo.

Elas são juridicamente equiparadas ao território terrestre, sendo que qualquer restrição a essa soberania deve ser tomada e interpretada de maneira restritiva. As baías serão consideradas águas interiores desde que as linhas de baixa-mar ou linha de base dos pontos naturais de suas entradas não excedam 24 milhas náuticas, sendo que também são considerados parte das águas interiores os golfos, portos e ancoradouros e os estuários.

\subsubsection{Mar territorial e zona contígua}

O mar territorial é a zona que compreende 12 milhas náuticas a partir da linha de base, onde o Estado ainda tem soberania e o direito exclusivo de pesca, extração e percepção dos recursos naturais que ali crescem, ou que o mar lança nas margens, sendo que os estrangeiros nada têm a dizer a respeito. Também o direito exclusivo de navegação, passagem, entrada e estadia em portos ou

${ }^{12}$ CALIXTO, Robson José. Incidentes marítimos: história, direito marítimo e perspectivas num mundo em reforma da ordem internacional. São Paulo: Aduaneiras, 2004. p. 149.

${ }^{13}$ MATTOS, Adherbal Meira. O novo Direito do Mar. Rio de Janeiro: Renovar, 2008. p. 19. 
no litoral, "salvo as exceções que resultem da liberdade de comércio, hoje reconhecida na Europa, em razão de Tratados, de leis e de costumes". ${ }^{14}$

\begin{abstract}
O mar territorial é a faixa de mar que se estende desde a linha de base até distância que não deve exceder 12 milhas marítimas da costa e sobre a qual o Estado exerce a sua soberania, com algumas limitações determinadas pelo Direito Internacional, inclusive em razão de questões de proteção ambiental.

Por sua vez, a zona contígua ao mar territorial é espaço no qual o Estado costeiro pode tomar $s$ medidas de fiscalização necessárias a evitar as infrações às leis e regulamentos aduaneiros, fiscais, de imigração ou sanitários, bem como reprimir as infrações às leis e regulamentos, no seu território ou no sei mar territorial. Esta não pode estender-se além de 24 milhas marítimas, contadas a partir das linhas de base, que servem para medir a largura do mar territorial. ${ }^{15}$
\end{abstract}

Já a Zona Contígua é aquela que compreende 24 milhas a partir da linha de base, sendo que o Estado pode tomar as medidas de fiscalização necessárias à sua segurança, conforme versa o Artigo $33^{\circ}$ da Convenção.

Artigo 33: Zona contígua

1. Numa zona contígua ao seu mar territorial, denominada zona contígua, o Estado costeiro pode tomar as medidas de fiscalização necessárias a:

a) evitar as infrações às leis e regulamentos aduaneiros, fiscais, de imigração ou sanitários no seu território ou no seu mar territorial;

b) reprimir as infrações às leis e regulamentos no seu território ou no seu mar territorial.

2. A zona contígua não pode estender-se além de 24 milhas marítimas, contadas a partir das linhas de base que servem para medir a largura do mar territorial.

\subsubsection{Zona econômica exclusiva}

O conceito de Zona Econômica Exclusiva, a partir daqui denominada ZEE, foi uma das inovações trazidas pela Convenção de Montego Bay de 1982, sendo definida no Artigo 55 da Convenção, o qual diz:

Artigo 55: A Zona Econômica Exclusiva é uma zona situada além do mar territorial e a este adjacente, sujeita ao regime jurídico estabelecido na presente Parte, segundo o qual os direitos e a jurisdição do Estado costeiro e os direitos

${ }^{14}$ MATTOS, 2008 apud CASELLA, Paulo Borba. Direito internacional dos espaços. São Paulo: Atlas, 2009. p. 385.

${ }^{15}$ CASELLA, Paulo Borba. Direito internacional dos espaços. São Paulo: Atlas, 2009. p. 385. e liberdades dos demais Estados estão regidos pelas disposições pertinentes da presente Convenção.

A largura da ZEE é de 200 milhas náuticas, medidas a partir da linha de base, também determinadora da extensão do mar territorial. De acordo com Casella, a figura da ZEE teve origem nas tentativas unilaterais de proteção da soberania dos Estados sobre o mar e a plataforma continental, principalmente relacionadas com a navegação e com a segurança do Estado ribeirinho. ${ }^{16}$ É reconhecido o direito de soberania do Estado costeiro para a exploração dos recursos naturais, sua utilização para fins econômicos e instalação de estruturas, mas não há soberania do Estado costeiro de uma maneira efetiva sobre a ZEE."Esta foi a fórmula adotada: fala-se em jurisdição e em direitos econômicos, estes de caráter exclusivo, do Estado costeiro, ao mesmo tempo em que se assegura a liberdade de navegação e de passagem inocente aos demais Estados. ${ }^{17}$

\subsubsection{Plataforma continental}

Antes de o conceito de ZEE ter sido concebido pelos juristas, também não existia a concepção de plataforma continental fora da noção geográfica que ela carrega.

Antes a questão em relação à plataforma continental dizia respeito aos limites operacionais, visto que a tecnologia não havia ainda alcançado o necessário grau de desenvolvimento para que sua exploração econômica pudesse ser cogitada. Atualmente, com a mudança de foco, em relação à plataforma continental, internacionalmente a questão maior se põe em relação à conservação desta. ${ }^{18}$

Segundo os geólogos, os continentes se encontram assentados sobre uma espécie de base ou plataforma submersa, com ligeiro declive, chegando à profundidade de 200 metros, caindo então para as profundidades abissais subitamente. ${ }^{19}$

Esta denominação foi utilizada pela primeira vez em uma declaração do Governo dos Estados Unidos em 1945, assinada pelo presidente Truman, sobre as zonas de conservação de pescarias e também sobre os recursos

${ }^{16}$ CASELLA, Paulo Borba. Direito internacional dos espaços. São Paulo: Atlas, 2009. p. 400.

${ }^{17}$ Ibidem, p. 403.

${ }^{18}$ Ibidem, p. 421.

${ }^{19}$ CASELLA, Paulo Borba. Direito internacional dos espaços. São Paulo: Atlas, 2009. 
naturais submarinos, sendo seguidos por outros países, fazendo uma terminologia puramente geográfica ser incorporada ao Direito Internacional, para que o interesse nacional e internacional de utilização dos recursos lá disponíveis fosse regulamentado.

\section{Estatuto e instituição do tribunal para o direito do mar}

A Convenção de Montego Bay de 1982, em seu Anexo VI, traz o Estatuto do Tribunal Internacional para o Direito do Mar, tendo sua sede na cidade de Hamburgo, na Alemanha, sendo composto de 21 membros, que constituem representação dos principais sistemas jurídicos do mundo, sendo distribuídos geográfica e equitativamente.

O Tribunal conta com uma Câmara de Controvérsias dos Fundos Marinhos, competente para solucionar controvérsias entre Estados Partes e à Autoridade Internacional dos Fundos Marinhos e entre partes num contrato, referentes a todas as questões que lhe sejam submetidas nos termos da Convenção. O Tribunal pode constituir Câmaras Especiais para conhecer de determinadas categorias de controvérsias. ${ }^{20}$

O direito aplicável será o constante na Convenção ou em outras normas internacionais, sendo que ainda há a possibilidade de resolução do conflito por equidade, que consiste na aplicação do "sentimento ideal de justiça aos casos concretos", ${ }^{21}$ com a função de completar o direito, sendo aplicada como regime subsidiário. As proposições de solução de controvérsias do Tribunal Internacional para o Direito do Mar são compulsórias, a não ser que o Estado, durante a ratificação, escolha outro meio de solução de controvérsias que não o Tribunal, como, por exemplo, a Corte Internacional de Justiça.

Há ainda a faculdade de se instaurar um tribunal arbitral, composto por cinco membros que devem ser escolhidos dentre uma lista elaborada pelo Secretário Geral da ONU, sendo que nas duas hipóteses, tanto o laudo arbitral quanto a sentença são considerados definitivos, levando em consideração que, com relação ao laudo arbitral, é possível haver um acordo entre as partes, caso

\footnotetext{
${ }^{20}$ MATTOS, Adherbal Meira. O novo Direito do Mar. Rio de Janeiro: Renovar, 2008. p. 105.

${ }^{21}$ PEREIRA, André Gonçalves; QUADROS, Fausto de. Manual de direito internacional público. 3. ed. Coimbra: Almedina, 2005. p. 275.
}

elas optem por um procedimento de apelação, o que será discutido mais para frente.

O Tribunal Internacional para o Direito do Mar tem jurisdição sobre todas as disputas acerca da matéria, conflitos de interpretação ou aplicação da Convenção, bem como tem o poder de adjudicar casos enviados por partes em outro Tratado, se ele o permitir. ${ }^{22}$

\begin{abstract}
O Tribunal estabeleceu, de acordo com a Convenção, a Câmara de Disputas sobre os fundos marinhos que consiste em onze juízes selecionados do Tribunal Internacional para o Direito do Mar e, sob esta Câmara, câmaras ad hoc podem ser estabelecidas quando necessárias. Além disto, o Tribunal estabeleceu quatro câmaras especiais, incluindo: a Câmara de Procedimentos Sumários, que consiste em cinco juízes fixos e dois alternados; a Câmara de Disputas sobre Pesca, que consiste em sete juízes e está disponível para lidar com disputas envolvendo a conservação e administração dos recursos marinhos vivos; a Câmara de Disputas acerca do Ambiente Marinho, que também consiste em sete juízes e está disponível para lidar com conflitos relacionados à proteção e preservação do ambiente marinho. Outra câmara especial importante é a Câmara para Conflitos de Delimitação, que foi criada em março de 2007 e consiste em oito juízes ${ }^{23}$
\end{abstract}

\section{1 métodos de Resolução de conflitos}

Apesar de a maioria dos conflitos ser resolvida por meio de meios políticos, como as negociações bilaterais, a arbitragem e a adjudicação ainda são de suma importância como componentes da solução de controvérsias. ${ }^{24}$ A Con-

${ }^{22}$ KEYUAN, Zou. The International Tribunal for the Law of the Sea: Procedures, Practices, and Asian States. Ocean Developmend and International Law, 41,131-151, 2010. p. 2.

${ }^{23}$ KEYUAN, Zou. The International Tribunal for the Law of the Sea: Procedures, Practices, and Asian States. Ocean Developmend and International Law, 41,131-151, 2010. p. 2: The ITLOS has, pursuant to the LOS Convention, established the Seabed Disputes Chamber that consists of judges selected from the ITLOS and, under this chamber, ad hoc chambers can be established when they are necessary. In addition, the Tribunal has established four special chambers including: the Chamber of Summary Procedure, which consists five judges and two alternates; the Chamber for Fisheries Disputes, which consists of seven judges and is available to deal with disputes concerning the conservation and management of marine living resources; the Chamber for Marine Environment Disputes, which also consists of seven judges and is available to deal with disputes relating to the protection and preservation of the marine environment. Another important special chamber is the Chamber for Maritime Delimitation Disputes, which was created in March 2007 and consists of eight judges

${ }^{24}$ Ibidem, p. 1. 
Tabela 1 - Lista de Casos no Tribunal Internacional para o Direito do Mar

\begin{tabular}{|c|c|}
\hline Caso No. 1 & The M/V "SAIGA" Case (Saint Vincent and the Grenadines v. Guinea), Prompt Release \\
\hline Caso No. 2 & The M/V “SAIGA” (No. 2) Case (Saint Vincent and the Grenadines v. Guinea) \\
\hline Casos No. 3 e 4 & Southern Bluefin Tuna Cases (New Zealand v. Japan; Australia v. Japan), Provisional Measures \\
\hline Caso No. 5 & The "Camouco" Case (Panama v. France), Prompt Release \\
\hline Caso No. 6 & The "Monte Confurco" Case (Seychelles v. France), Prompt Release \\
\hline Caso No. 7 & $\begin{array}{l}\text { Case concerning the Conservation and Sustainable Exploitation of Swordfish Stocks in the South- } \\
\text { Eastern Pacific Ocean (Chile / European Union) }\end{array}$ \\
\hline Caso No. 8 & The "Grand Prince" Case (Belize v. France), Prompt Release \\
\hline Caso No. 9 & The “Chaisiri Reefer 2" Case (Panama v. Yemen), Prompt Release \\
\hline Caso No. 10 & The MOX Plant Case (Ireland v. United Kingdom), Provisional Measures \\
\hline Caso No. 11 & The "Volga" Case (Russian Federation v. Australia), Prompt Release \\
\hline Caso No. 12 & $\begin{array}{l}\text { Case concerning Land Reclamation by Singapore in and around the Straits of Johor (Malaysia v. } \\
\text { Singapore), Provisional Measures }\end{array}$ \\
\hline Caso No. 13 & The "Juno Trader" Case (Saint Vincent and the Grenadines v. Guinea-Bissau), Prompt Release \\
\hline Caso No. 14 & The "Hoshinmaru" Case (Japan v. Russian Federation), Prompt Release \\
\hline Caso No. 15 & The “Tomimaru” Case (Japan v. Russian Federation), Prompt Release \\
\hline Caso No. 16 & $\begin{array}{l}\text { Dispute concerning delimitation of the maritime boundary between Bangladesh and Myanmar in } \\
\text { the Bay of Bengal (Bangladesh/Myanmar) }\end{array}$ \\
\hline Caso No. 17 & $\begin{array}{l}\text { Responsibilities and obligations of States sponsoring persons and entities with respect to activities } \\
\text { in the Area (Request for Advisory Opinion submitted to the Seabed Disputes Chamber) }\end{array}$ \\
\hline Caso No. 18 & The M/V “Louisa” Case (Saint Vincent and the Grenadines v. Kingdom of Spain) \\
\hline Caso No. 19 & The M/V “Virginia G” Case (Panama/Guinea-Bissau) \\
\hline
\end{tabular}

Fonte: Adaptado da web site do Tribunal Internacional para o Direito do Mar. Disponível em: <http://www.itlos.org/index. php?id=35\&L=0>. Acesso em: 15 set. 2011.

venção de Montego Bay de 1982, em sua parte XV, trata da solução de controvérsias, sendo que na seção 1, é estabelecido que qualquer controvérsia relacionada à interpretação ou à aplicação da Convenção deve ser remetida às disposições de solução de conflitos que se encontram na Carta das Nações Unidas, Artigo 33, o qual dispõe:

Artigo 33: 1. As partes de uma controvérsia, que possa vir a constituir uma ameaça à paz e à segurança internacionais, procurarão, antes de tudo, chegar a uma solução por negociação, inquérito, mediação, conciliação, arbitragem, solução judicial, recurso a entidades ou acordos regionais, ou a qualquer outro meio pacífico à sua escolha.

2. O Conselho de Segurança convidará, quando julgar necessário, as referidas partes, a resolver, por tais meios, suas controvérsias.

Isso, porém, não significa que os Estados estejam prejudicados em seu direito de acordarem uma solução pacífica por meios de sua própria escolha. ${ }^{25}$

${ }^{25}$ MATTOS, Adherbal Meira. O novo Direito do Mar. Rio de Janeiro: Renovar, 2008. p. 104.
Os procedimentos previstos na Convenção só serão aplicados se as partes não tiverem alcançado uma solução amigável. Se tiverem firmado acordos bilaterais, regionais ou gerais sobre a matéria, tal procedimento será preferencialmente aplicado, sempre presente a troca de opinião, entre as partes, sobre a controvérsia. ${ }^{26}$

Desde a entrada em vigor de Convenção em 1994, cinco casos haviam sido resolvidos com arbitragem (dados de 2010), sendo que ela permite que os Estados signatários remetam à arbitragem para solução e conflitos envolvendo pesca, proteção do ambiente marinho, pesquisa cientifica, navegação e casos de poluição por navios. ${ }^{27}$

A grande maioria dos casos é sobre a pronta libertação de embarcações e de suas tripulações, sendo prevista no Artigo 292 da Convenção, enquanto outros tratam de medidas provisórias decretadas pelo Tribunal, de acordo com o Artigo 290 da Convenção.

\footnotetext{
${ }^{26}$ MATTOS, Adherbal Meira. O novo Direito do Mar. Rio de Janeiro: Renovar, 2008. p. 104.

${ }^{27}$ KEYUAN, Zou. The International Tribunal for the Law of the Sea: Procedures, Practices, and Asian States. Ocean Developmend and International Law, 41,131-151, 2010. p. 2.
} 
De acordo com o Artigo 27 do Estatuto do Tribunal, os trâmites do processo são definidos pelo próprio Tribunal, sendo que é ele que institui prazos de prescrição e perempção. As decisões tomadas por ele devem ser pela maioria de todos os membros presentes, como discorre o Artigo 29 e, em caso de empate, é o voto do Presidente ou do membro do Tribunal que o substitui no momento da votação.

Se um Estado considerar que tem interesse de natureza jurídica sobre determinada disputa e sentir que ela possa ser afetada por qualquer decisão do tribunal, pode submetê-la a um pedido de intervenção, nos termos do Artigo 31 do Estatuto.

De acordo com o Artigo 33 do Estatuto, toda a sentença proferida pelo Tribunal tem caráter definitivo:

Artigo 33: Natureza definitiva e força obrigatória da sentença

A sentença do Tribunal será definitiva e deverá ser acatada por todas as partes na controvérsia.

A sentença não terá força obrigatória senão para as partes e no que se refere a uma controvérsia determinada.

Em caso de desacordo sobre o sentido ou alcance da sentença, compete ao Tribunal interpretála, a pedido de qualquer das partes.

Apesar de ser o único Tribunal especializado para as disputas acerca do Direito do Mar, há constrições e limitações quanto à sua atuação, fazendo com que ela se torne relativamente inábil. ${ }^{28} \mathrm{~A}$ primeira dessas constrições diz respeito à competição de jurisdição, ou seja, ele possui competência concorrente com a Corte Internacional de Justiça e tribunais arbitrais e, por ser uma instituição relativamente nova, passa por uma posição de desvantagem com relação às outras cortes. ${ }^{29}$

Outro constrangimento ocorre com relação à escolha dos procedimentos de solução de controvérsias. Dos Estados signatários da Convenção, somente treze selecionaram o Tribunal Internacional para o Direito do Mar como a primeira opção para a solução de disputas, sendo que os outros transitam entre a Corte Internacional de Justiça e Tribunais Arbitrais.

${ }^{28}$ KEYUAN, Zou. The International Tribunal for the Law of the Sea: Procedures, Practices, and Asian States. Ocean Developmend and International Law, 41,131-151, 2010. p. 6.

${ }^{29}$ Ibidem, loc. cit.
Ainda há a possibilidade, sob o Artigo 298 da Convenção, que os Estados excluam completamente a competência do Tribunal e suas medidas compulsórias de resolução de conflitos em determinadas matérias

Artigo 298: Exceções de caráter facultativo à aplicação da Seção 2

Ao assinar ou ratificar a presente Convenção ou a ela aderir, ou em qualquer outro momento ulterior, um Estado pode, sem prejuízo das obrigações resultantes da seção 1, declarar por escrito não aceitar um ou mais dos procedimentos estabelecidos na seção 2, com respeito a uma ou várias das seguintes categorias de controvérsias:

a) i) as controvérsias relativas à interpretação ou aplicação dos artigos 15, 74 e 83 referentes à delimitação de zonas marítimas, ou às baías ou títulos históricos, com a ressalva de que o Estado que tiver feito a declaração, quando tal controvérsia, surgir depois da entrada em vigor da presente Convenção e quando não se tiver chegado a acordo dentro de um prazo razoável de negociações entre as partes, aceito, a pedido de qualquer parte na controvérsia, submeter a questão ao procedimento de conciliação nos termos da seção 2 do Anexo V; além disso, fica excluída de tal submissão qualquer controvérsia que implique necessariamente o exame simultâneo de uma controvérsia não solucionada relativa à soberania ou outros direitos sobre um território continental ou insular;

ii) depois de a comissão de conciliação ter apresentado o seu relatório, no qual exporá as razões em que se fundamenta, as partes negociarão um acordo com base nesse relatório; se essas negociações não resultarem num acordo, as partes deverão, salvo acordo em contrário, submeter, por mútuo consentimento, a questão a um dos procedimentos previstos na seção 2 ;

iii) esta alínea não se aplica a nenhuma controvérsia relativa à delimitação de zonas marítimas que tenha sido definitivamente solucionada por acordo entre as partes, nem a qualquer controvérsia que deva ser solucionada de conformidade com um acordo bilateral ou multilateral obrigatório para essas partes;

b) as controvérsias relativas a atividades militares, incluídas as atividades militares de embarcações e aeronaves de Estado utilizadas em serviços não comerciais, e as controvérsias relativas a atividades destinadas a fazer cumprir normas legais tendo em vista o exercício de direitos soberanos ou da jurisdição excluídas, nos termos dos parágrafos $2^{\circ}$ ou $3^{\circ}$ do artigo 297 , da jurisdição de uma corte ou tribunal;

c) as controvérsias a respeito das quais o Conselho de Segurança das Nações Unidas esteja a exercer as funções que lhe são conferidas pela Carta das Nações Unidas, a menos que o Conselho de Segurança retire a questão da sua ordem do dia ou convide as partes a solucioná-las pelos meios previstos na presente Convenção. 
2. O Estado Parte que tiver feito uma declaração nos termos do parágrafo $1^{\circ}$ poderá retirá-la em qualquer momento ou convir em submeter a controvérsia, excluída em virtude dessa declaração, a qualquer dos procedimentos estabelecidos na presente Convenção.

3. Um Estado Parte que tiver feito uma declaração nos termos do parágrafo $1^{\circ}$ não pode submeter a controvérsia pertencente à categoria de controvérsias excluídas, a qualquer dos procedimentos previstos na presente Convenção, sem o consentimento de qualquer outro Estado Parte com o qual estiver em controvérsia.

4. Se um dos Estados Partes tiver feito uma declaração nos termos da alínea a) do parágrafo $1^{\circ}$, qualquer outro Estado Parte poderá submeter, contra a parte declarante, qualquer controvérsia pertencente a uma das categorias executadas ao procedimento especificado em tal declaração.

5. Uma nova declaração ou a retirada de uma declaração não afetará de modo algum os procedimentos em curso numa corte ou tribunal nos termos do presente artigo, salvo acordo em contrário da partes.

6. As declarações e as notificações de retirada das declarações nos termos do presente artigo serão depositadas junto do Secretário Geral das Nações Unidas, o qual enviará cópias das mesmas aos Estados Partes.

O grande motivo da realização de exclusões relacionadas às matérias acima citadas é a preferência dos Estados de resolver essas questões pelos meios políticos ou diplomáticos, como as negociações bilaterais e as consultas, o que acaba desencorajando o uso do Tribunal Internacional para o Direito do Mar por causa do grande número de ressalvas assinadas (26 Estados, até 2009). ${ }^{30}$

É e se pensar que a aversão dos Estados às resoluções judiciais é inerente à estrutura da sociedade internacional direcionada por processos políticos e onde os interesses individualistas dos Estados são onipresentes. Isto explica a subutilização das cortes e tribunais internacionais (tradução nossa) ${ }^{31}$.

${ }^{30}$ KEYUAN, Zou. The International Tribunal for the Law of the Sea: Procedures, Practices, and Asian States. Ocean Developmend and International Law, 41,131-151, 2010. p. 8.

${ }^{31}$ NDIAYE, Tafsir Malick. The advisory function of the International Tribunal for the Law of the Sea. Chinese Journal of International Law, n. 9, p. 565-587., Oxford: Oxford University Press, 2010, p.566. One could think that the abhorrence of States for judicial settlement is inherent in the very structure of an international society fashioned by political processes and where the individualistic interests of States are omnipresent. This explains the under-utilization of international courts and tribunals.
É também possível notar que o envio de questões às cortes judiciais acontece apenas em ocorrências consideradas como puramente judiciais, consistindo em disputas que teoricamente não atraíram crise interna e não perturbe a realização das políticas de interesses de um determinado Estado, em outras palavras, de acordo com Tafsir Malick Ndiaye, as disputas trazidas perante as Cortes e Tribunais internacionais possuem menor significância. ${ }^{32}$

\subsubsection{Pareceres consultivos}

A função consultiva do Tribunal Internacional para o Direito do Mar pode ser utilizada quando há falta de jurisprudência a respeito de determinada matéria e, apesar de não ter caráter obrigatório nem formar precedentes, os Pareceres Consultivos emitidos têm uma aceitação geral perante os signatários da Convenção. ${ }^{33}$ É o mais utilizado por ser um método menos constrangedor do que um litígio perante o Tribunal, principalmente por evitar o risco jurídico de remeter uma questão a um Tribunal ou Corte Internacional, cujas decisões são regidas pelo princípio da res judicata ou coisa julgada. ${ }^{34}$

Ao contrário da Corte Internacional de Justiça, em que somente Estados podem ser parte de uma ação, sendo que organizações internacionais não possuem capacidade perante ela, o Tribunal Internacional para o Direito do Mar estabelece diversos órgãos, já citados anteriormente, sendo que ele próprio é considerado uma organização internacional autônoma perante as Nações Unidas, gozando de status independente dos outros órgãos formadores da Convenção. ${ }^{35}$

A função consultiva do Tribunal é exercida pela Câmara de Controvérsias dos Fundos Marinhos, de acordo com os termos da Convenção (Seção I). A corte principal do Tribunal Internacional para o Direito do Mar pode, entretanto prestar

${ }^{32}$ NDIAYE, Tafsir Malick. The advisory function of the International Tribunal for the Law of the Sea. Chinese Journal of International Law, n. 9, p. 565-587., Oxford: Oxford University Press, 2010, p.566. One could think that the abhorrence of States for judicial settlement is inherent in the very structure of an international society fashioned by political processes and where the individualistic interests of States are omnipresent. This explains the under-utilization of international courts and tribunals.

${ }^{33}$ NDIAYE, Tafsir Malick. The advisory function of the International Tribunal for the Law of the Sea. Chinese Journal of International Law, Oxford, Oxford University Press, n. 9, p. 565-587, 2010. p.565.

${ }^{34}$ Ibidem.

${ }^{35}$ Ibidem. 
um parecer consultivo baseado em outros acordos internacionais (Seção II) (tradução nossa) ${ }^{36}$.

De regra, a possibilidade de se obter um parecer consultivo pertence somente às organizações internacionais, sendo que não há partes ou reivindicações envolvidas nesse tipo de procedimento ${ }^{37}$, sendo que a única maneira possível de ter acesso à Câmara de Controvérsias dos Fundos Marinhos é mediante um pedido, dependendo da matéria a ser discutida, sendo ela também aberta aos órgãos que compõem o Tribunal, como a Assembleia e o Conselho, a respeito de dúvidas que possam surgir a partir do escopo de suas atividades.

\begin{abstract}
Artigo 191: Pareceres consultivos
A Câmara de Controvérsias dos Fundos Marinhos emitirá, a pedido da Assembléia ou do Conselho, pareceres consultivos sobre questões jurídicas que se suscitem no âmbito das suas atividades. Tais pareceres serão emitidos com caráter de urgência.
\end{abstract}

Para que a Câmara tenha competência sobre o pedido enviado pelos órgãos do Tribunal, é necessário avaliar se o requerimento realmente se encontra dentro do escopo das atividades destes órgãos.

Os procedimentos para submissão e trâmite dos pareceres consultivos são descritos no Artigo 188 da Convenção, que diz:

Artigo 188: Submissão de controvérsias a uma câmara especial do Tribunal Internacional do Direito do Mar ou a uma câmara ad hoc da Câmara de Controvérsias dos Fundos Marinhos ou a uma arbitragem comercial obrigatória

1. As controvérsias entre Estados Partes referidas na alínea a) do artigo 187 podem ser submetidas:

a) a pedido das partes na controvérsia, a uma câmara especial do Tribunal Internacional do Direito do Mar constituída de conformidade com os artigos 15 e 17 do Anexo VI; ou

b) a pedido de qualquer das partes na controvérsia, a uma câmara ad hoc da Câmara de Controvérsias dos Fundos Marinhos constituída de conformidade com o artigo 36 do Anexo VI.

${ }^{36}$ NDIAYE, Tafsir Malick. The advisory function of the International Tribunal for the Law of the Sea. Chinese Journal of International Law, Oxford, Oxford University Press, n. 9, p. 565-587, 2010. p. 570: The advisory function of the Tribunal is exercised by the Seabed Disputes Chamber within the terms of the Convention (Section I). The ITLOS full Court may however render an advisory opinion based on other international agreements (Section II).

${ }^{37}$ Ibidem.
2. a) As controvérsias relativas à interpretação ou execução de um contrato referidas na subalinea i) da alínea c) do artigo 187 serão submetidas, a pedido de qualquer das partes na controvérsia, a uma arbitragem comercial obrigatória, salvo acordo em contrário das partes. O tribunal arbitral comercial, a que a controvérsia seja submetida, não terá jurisdição para decidir sobre qualquer questão de interpretação da presente Convenção. Quando a controvérsia suscitar também uma questão de interpretação da Parte XI e dos Anexos com ela relacionados relativamente às atividades na Área, essa questão será remetida à Câmara de Controvérsias dos Fundos Marinhos para decisão.

b) Se, no inicio ou no decurso de tal arbitragem, o tribunal arbitral comercial determinar, a pedido de uma das partes na controvérsia ou por iniciativa própria, que a sua decisão depende de uma decisão da Câmara de Controvérsias dos Fundos Marinhos, o tribunal arbitral remeterá tal questão à Câmara para esta se pronunciar. O tribunal arbitral proferirá em seguida sentença de conformidade com a decisão da Câmara de Controvérsias dos Fundos Marinhos.

c) Na ausência de disposição no contrato sobre o procedimento arbitral a aplicar a uma controvérsia, a arbitragem processar-se-á de conformidade com as Regras de Arbitragem da Comissão das Nações Unidas sobre o Direito Comercial Internacional (UNCITRAL) ou com quaisquer outras regras de arbitragem sobre a matéria estabelecida nas normas, regulamentos e procedimentos da Autoridade, salvo acordo em contrário das partes na controvérsia.

Os procedimentos terão que estar de acordo com as regras aplicadas nos casos contenciosos, sempre que possível. ${ }^{38}$ Os juízes serão apontados e as partes podem ser tanto Estados quanto organizações internacionais, pessoas físicas ou jurídicas e até mesmo empresas estatais.

O escrivão deve imediatamente notificar a requisição de um parecer consultivo a todos os Estados Partes. A Câmara ou seu Presidente, se a Câmara não está em funcionamento, deve identificar a organização inter-governamental que pode prover as informações necessárias para a questão. O escrivão deve notificar as organizações de tais requisições. Os Estados Partes e as organizações devem ser convidados a apresentar suas declarações escritas dentro do prazo estabelecido pela Câmara. Estas declarações devem ser comunicadas aos Estados Partes e organizações que fizeram tais declarações. A Câmara deve então prover o prazo para a réplica. A câmara deve também decidir se defesas

\footnotetext{
${ }^{38}$ NDIAYE, Tafsir Malick. The advisory function of the International Tribunal for the Law of the Sea. Chinese Journal of
} International Law, Oxford, Oxford University Press, n. 9, p. 565-587, 579, 2010. 
orais deverão ser realizadas e, se sim, estabelecer a data para a abertura de tais procedimentos. As declarações escritas e seus respectivos documentos devem ser feitos públicos assim que possível após terem sido apresentados à Câmara (tradução nossa). ${ }^{39}$

Depois dos procedimentos acima descritos, a Câmara completa as suas deliberações, que devem ser apresentadas em uma audiência pública da Assembleia, sendo que deve conter uma série de informações pré-definidas pela Convenção, como a data de declaração expressa, os nomes dos juízes participantes, as questões que foram discutidas etc.

A expedição de pareceres consultivos fora do âmbito da Câmara de Controvérsias dos Fundos Marinhos e a possibilidade do próprio Tribunal Internacional para o Direito do Mar de expedir tais pareceres não estão propriamente estabelecidos na Convenção ou no Estatuto do Tribunal, mas sim nas regras do Tribunal. ${ }^{40}$

Os pareceres consultivos, como já dito anteriormente, não são considerados obrigatórios, pois não possuem força de res judicata, mas possuem uma autoridade moral $^{41}$ que acaba por garantir sua aplicação.

${ }^{39}$ NDIAYE, Tafsir Malick. The advisory function of the International Tribunal for the Law of the Sea. Chinese Journal of International Law, Oxford, Oxford University Press, n. 9, p. 565-587, 2010. The Registrar shall forthwith give notice of the request for an advisory opinion to all States Parties. The Chamber, or its President if the Chamber is not sitting, shall indentify the inter-governmental organizations which are likely to be able to furnish information on the question. The Registrar shall give notice of the request to such organizations. States Parties and the organizations shall be invited to present written statements on the question within a time limit set by the Chamber. Such statements shall be communicated to State Parties and organizations which have made written statements. The Chamber may set a further time limit within which such States Parties and organizations may present written statements on the statements made. The Chamber shall also decide whether oral proceedings shall be held and, if so, set the date for the opening of such proceedings. States Parties and the organizations shall be invited to make oral statements at the proceedings. Written statements and accompanying documents shall be made available to the public as soon as possible after they have been presented to the Chamber.

${ }^{40}$ NDIAYE, Tafsir Malick. The advisory function of the International Tribunal for the Law of the Sea. Chinese Journal of International Law, Oxford, Oxford University Press, n. 9, p. 565-587, 2010.

${ }^{41}$ Ibidem, p. 579.

\subsubsection{Medidas provisórias}

Ao contrário dos pareceres consultivos, as medidas provisórias possuem um caráter obrigatório com relação às partes envolvidas. Quando a Convenção estabeleceu que o Tribunal teria poder de prescrever tais medidas, ficou claro que isso representava uma inovação que faria com que o poder das cortes e tribunais internacionais com competência sobre disputas acerca do Direito do Mar fosse aperfeiçoado ${ }^{42}$.

A natureza obrigatória dessas medidas foi confirmada por meio da jurisprudência e outras provisões. O Artigo 290 da Convenção, parágrafo 6, diz que “[...] as partes na controvérsia devem cumprir sem demora quaisquer medidas provisórias decretadas nos termos do presente artigo" e o fato de as medidas provisórias serem prescritas por um determinado período de tempo não parece afetar sua observância em nenhum momento. ${ }^{43}$

Artigo 290: Medidas provisórias

1. Se uma controvérsia tiver sido devidamente submetida a uma corte ou tribunal que se considere, prima facie, com jurisdição nos termos da presente Parte ou da seção 5 da Parte XI, a corte ou tribunal poderá decretar quaisquer medidas provisórias que considere apropriadas às circunstâncias, para preservar os direitos respectivos das partes na controvérsia ou impedir danos graves ao meio marinho, até decisão definitiva.

2. As medidas provisórias podem ser modificadas ou revogadas desde que as circunstâncias que as justificaram se tenham modificado ou deixado de existir.

3 As medidas provisórias só podem ser decretadas, modificadas ou revogadas, nos termos do presente artigo, a pedido de uma das partes na controvérsia e após ter sido dada às partes a oportunidade de serem ouvidas.

4. A corte ou tribunal notificará imediatamente as partes na controvérsia e, se julgar apropriado, outros Estados Partes, de qualquer medida provisória ou de qualquer decisão que a modifique ou revogue.

5. Enquanto não estiver constituído o tribunal arbitral ao qual uma controvérsia esteja a ser submetida nos termos da presente seção, qualquer corte ou tribunal, escolhido de comum acordo pelas partes ou, na falta de tal acordo,

$\overline{42}$ VICUÑA, Francisco Orrego. The International Tribunal for The Law of the Sea and Provisional Measures: Settled Issues and Pending Problems. The International Journal of Maritime and Coastal Law, Koninklijke Brill NV, v.22, n.3, p. 451-462, 2007.

${ }^{43}$ Ibidem, p. 453. 
dentro de duas semanas subseqüentes à data do pedido de medidas provisórias, o Tribunal Internacional do Direito do Mar, ou, tratandose de atividades na Área, a Câmara de Controvérsias dos Fundos Marinhos, pode decretar, modificar ou revogar medidas provisórias nos termos do presente artigo, se considerar, prima facie, que o tribunal a ser constituído teria jurisdição e que a urgência da situação assim o requer. Logo que estiver constituído, o tribunal ao qual a controvérsia foi submetida pode, atuando de conformidade com os parágrafos $1^{\circ}$ a $4^{\circ}$, modificar, revogar ou confirmar essas medidas provisórias.

6. As partes na controvérsia devem cumprir sem demora quaisquer medidas provisórias decretadas nos termos do presente artigo.

Apesar de o parágrafo $2^{\circ}$ do mesmo artigo prover que uma medida provisória pode ser revogada ou anulada em caso de modificação das circunstâncias que a trouxeram em discussão, isso não significa que as partes não possam trazer à corte as mesmas alegações sobre uma mesma questão no caso de uma modificação de contexto. Caso o Tribunal consiga chegar a uma decisão final, seja por análise de mérito ou por falta de competência sobre a causa, as medidas podem ser revogadas, sendo necessária uma declaração expressa.

O Tribunal ainda contribuiu para a clarificação de um número de aspectos referentes aos requerimentos necessários para o requerimento de medidas provisórias como, por exemplo, a jurisdição e a competência dele sobre determinadas matérias, bem como sobre os poderes do próprio Tribunal em estabelecer essas medidas. ${ }^{44}$ Há certa delimitação do poder do Tribunal em realizar ações de sua própria iniciativa (proprio motu), como podemos observar no parágrafo $3^{\circ}$ do Artigo 290, onde está estabelecido que uma medida provisória somente pode ser revogada a pedido de uma das partes.

Também é interessante notar que a única situação na qual o Tribunal pode agir proprio motu é no contexto de revisar medidas provisórias adotadas pela Câmara de Procedimentos Sumários, como previsto no Artigo 91 (2) das Regras do Tribunal. Foi sugerido que este limite de poder também afetará a Corte Internacional de Justiça quando da decisão de medidas provisórias sob o Artigo 290 da Convenção.

${ }^{44}$ VICUÑA, Francisco Orrego. The International Tribunal for The Law of the Sea and Provisional Measures: Settled Issues and Pending Problems. The International Journal of Maritime and Coastal Law, Koninklijke Brill NV, v.22, n.3, p. 451-462, 2007.
Uma segunda consideração é que este poder limitado também pode prover embasamento para aqueles que acreditam que o Tribunal somente pode prescrever medidas provisórias e não recomendações [...] na medida em que o requerimento de uma parte somente concerte estas medidas provisórias (tradução nossa). ${ }^{45}$

De acordo com Thomas A. Mensah, ${ }^{46}$ para que as partes não sofram constrangimentos com relação ao seu direito de agir, foram colocadas diversas condições e requerimentos que devem ser preenchidos para que os méritos de uma disputa possam ser apreciados, sendo as principais: (a) medidas provisórias constituem um instrumento excepcional e somente podem ser requeridas nos casos em que se julgue necessária e apropriada; (b) a aceitação de um pedido é uma decisão discricionária, sendo que só será concedida se o juiz concluir que os resultados pretendidos não podem ser alcançados sem ela; (c) uma corte ou tribunal não pode, a princípio, requerer uma medida provisória a não ser que tenha competência para julgar a causa; (d) o princípio objetivo das medidas provisórias é preservar o direito de ambas as partes, sendo que os princípios de justiça e equidade devem prevalecer, não sendo permitido que os interesses ou direitos de uma das partes seja prejudicado e, por fim; (e) elas são apropriadas somente para circunstâncias consideradas de urgência, havendo um risco considerável para uma ou todas as partes envolvidas que venha a causar um dano irreparável. ${ }^{47}$

As regras acima descritas valem para medidas provisórias prescritas tanto pelo Tribunal Internacional para o Direito do Mar quanto para a Corte Internacional

${ }^{45}$ VICUÑA, Francisco Orrego. The International Tribunal for The Law of the Sea and Provisional Measures: Settled Issues and Pending Problems. The International Journal of Maritime and Coastal Law, Koninklijke Brill NV, v.22, n.3, p. 451-462, 2007. It is also interesting t note that the only situation in which the Tribunal can proceed proprio motu is in the context of reviewing provisional measures adopted by the Chamber of Summary Procedure, as envisaged in Article 91 (2) of the Tribunal's Rules. It has been suggested that this limited power will also affect the International Court of Justice when deciding on provisional measures under Article 290 of the Convention. A second consideration I that this limited power also provides grounds for those who believe that the Tribunal could only prescribe provisional measures and not recommendations [...] since the request of a party only concerns such provisional measures.

${ }^{46}$ MENSAH, Thomas A. Provisional Measures in the International Tribunal for the Law of the Sea (ITLOS). Max-Planck-Institut für ausländisches öffentliches Recht und Volkrecht, 2002.

${ }^{47}$ Ibidem, p. 44. 
de Justiça, sendo que o propósito daquelas previstas no Artigo 290 da Convenção não está restrito a apenas preservar os direitos das partes envolvidas na disputa, mas também prevenir danos ao ambiente marinho.

Por isso, o Tribunal Internacional para o Direito do Mar pode ser solicitado a prescrever medidas provisórias, não necessariamente para preservar algum direito de alguma das partes que possa ser identificado, mas principalmente ou somente prevenir grandes danos ao ambiente marinho. Onde provas são produzidas para mostrar que um dano ao ambiente marinho pode ocorrer e o Tribunal Internacional para o Direito do Mar está convencido que isto é "apropriado sob as circunstâncias", esta ação deve ser utilizada (ou medidas restritivas devem ser impostas) para que o dano seja evitado, ele será competente para prescrever medidas provisórias, mesmo que não haja comprovação que algum direito ou direitos específicos de uma das partes requerendo a medida esteja em risco (tradução nossa). ${ }^{48}$

A emissão de medidas provisórias pelo Tribunal Internacional para o Direito do Mar é uma das características mais importantes do Tribunal, sendo que ele possui competência residual (residual jurisdiction) ${ }^{49}$ sob o parágrafo $5^{\circ}$ do Artigo 290 em casos que digam respeito ao Anexo VIII da Convenção (que trata da Arbitragem Especial). A partir disso, o Tribunal foi capaz de estabelecer uma linha jurisprudencial internacional de suma importância para o desenvolvimento do Direito Internacional, bem como do Direito do Mar.

${ }^{48}$ MENSAH, Thomas A. Provisional Measures in the International Tribunal for the Law of the Sea (ITLOS). Max-Planck-Institut für ausländisches öffentliches Recht und Volkrecht, 2002. p. 45-46. Hence, ITLOS may be requested to prescribe provisional measures, not necessarily to preserve any identifiable rights of any of the parties in the dispute but mainly or even solely to prevent serious harm to the marine environment. Where evidence is produced to show that serious harm to the marine environment might occur, and ITLOS is satisfied that it is "appropriate under the circumstances" that action should be taken (or measures of restraint must be imposed) to prevent such damage, it will be competent to prescribe provisional measures, even if there is no evidence that any specific right or rights of the party making the request for the provisional measures are at risk.

${ }^{49} \mathrm{MENSAH}$, Thomas A. Provisional Measures in the International Tribunal for the Law of the Sea (ITLOS). Max-PlanckInstitut für ausländisches öffentliches Recht und Volkrecht, 2002. p.54.

\section{A Jurisdição compulsória do tribunal: pontos fortes e fracos}

Desde sua instauração em 1994, o Tribunal Internacional para o Direito do Mar teve um número relativamente pequeno de casos, principalmente pelo fato de ser dada aos Estados a possibilidade de utilizar outras formas de resolução de conflitos, como a Corte Internacional de Justiça, que por ser uma corte mais antiga, acaba sendo a preferência dos Estados partes da Convenção.

A criação de uma jurisdição compulsória e o fato de o Tribunal ser aberto a Estados não signatários da Convenção, bem como a possibilidade de ele decidir casos não referentes a esta, é tido por Seymour ${ }^{50}$ como uma extensão excessiva da competência do Tribunal. Apesar dessa competência estendida, o Tribunal não teve um número muito significativo de casos, dada a existência da própria Corte Internacional de Justiça e tribunais arbitrais, ambos tidos por Seymor como experts na matéria de Direito do Mar.

Ao contrário da Convenção das Nações Unidas para o Direito do Mar de 1958, cuja parte relativa à solução de controvérsias era tida como opcional, a Convenção de 1982 a coloca como compulsória, sendo tida como um passo à frente por autores como Ndiaye e, sob o ponto de vista de Seymour, coloca uma barreira à liberdade de escolha dos Estados. Como já observado, a Convenção dá a possibilidade de os Estados signatários optarem ou não pelo uso do Tribunal, o que claramente pode ser tido como uma proteção à liberdade de escolha, mas que também representa agora uma barreira à compulsoriedade do Tribunal, tão criticada pelos Estados Unidos da América e autores contrários à Convenção de Montego Bay de 1982, como Groves e Seymour.

Deixando de lado as possibilidades de exceção à competência do Tribunal, as disputas tidas como compulsórias têm ainda quatro principais meios de serem resolvidas, sendo elas por meio da Corte Internacional de Justiça, tribunais arbitrais, tribunais arbitrais especiais e o próprio Tribunal, a chamada Fórmula de Montreux. ${ }^{51}$ Isso pode

${ }^{50}$ SEYMOUR, Jillaine. The International Tribunal for the Law of the Sea: A great Mistake? Journal of Global Studies, Indiana. p. 2.

${ }^{51}$ As compulsoriedades contidas na parte XV da Convenção foram negociadas em reuniões informais realizadas na cidade de Montreux na Suíça durante a Convenção sobre o Direito do Mar de Genebra de 1975, ficando estabelecido que as partes poderiam escolher entre as quatro formas de solução de controvérsias. 
levantar a questão sobre a necessidade de instauração de um Tribunal permanente para resolução de conflitos sobre a matéria, dado o leque de possibilidades que a própria Convenção oferece a seus signatários.

O fato é que existe a aprovação da instauração do Tribunal pela comunidade internacional. No quarto workshop regional realizado em Cingapura no ano de 2007, o vice-primeiro-ministro do país disse ser importante que o Tribunal seja competente para emitir pareceres consultivos, assim como a Corte Internacional de Justiça. Podemos perceber uma tentativa dos Estados de aumentar a competência deste, fenômeno chamado de creeping jurisdiction (jurisdição rastejante) por Kwiatkowska. ${ }^{52}$

Uma avaliação realizada em 2008 constatou que, até então, nenhum caso envolvendo a parte XV da Convenção (disposição sobre solução de controvérsias) tinha sido remetido à Corte Internacional de Justiça, tendo ela decidido apenas um caso que se relacionava brevemente com a matéria, entre a Malásia e Cingapura a respeito da soberania sobre a entrada oeste do Estreito de Cingapura, sendo que a sentença da Corte não trouxe nenhuma disposição da Convenção, ou até mesmo do Direito do Mar.

$\mathrm{Na}$ avaliação de Churchill realizada em 2009, foi remetido um caso à Corte, somando-se aos outros dois casos ainda pendentes (disputa territorial e marítima entre Nicarágua e Colômbia e disputa marítima entre Peru e Chile).$^{53} \mathrm{O}$ maior problema, de acordo com o próprio Churchill, é que parte da quantidade relativamente pequena de Estados que escolheram o Tribunal como foro principal se encontra distante geograficamente, e isso torna pouco provável que uma disputa surja entre eles.

A instauração desse Tribunal, bem como a utilização de procedimentos compulsórios (apesar das exceções que podem ser adotadas) servem para colocar em plena prática as provisões sobre solução de controvérsias trazidas na Convenção. Ele não é uma ofensa à liberdade de escolha, pois traz a possibilidade de as partes escolherem outros meios, tornando-se obrigatório a partir do momento em que nenhuma delas se manifesta contrariamente.

\footnotetext{
${ }^{52}$ KWIATKOWSKA apud. KLEIN, Natalie. Maritime Security and the Law of the Sea. Nova Iorque: Oxford University Press, 2011. p. 7.

${ }^{53}$ Dispute Settlement under the UN Convention on the Law of the Sea: Survey for 2009. International Journal of Marine and Coastal Law 2010. p. 479
}

De acordo com Ravin, o Tribunal existe para evitar abusos por parte dos Estados, e para manter a paz mundial, não sendo descartável ou um erro, como considera Seymour. A competência dele não é imposta, mas sim fruto de acordos entre os Estados signatários que optam ou não pela sua utilização, é exigido que as partes estejam de acordo com a existência de competência do Tribunal sobre o caso, não podendo então ser considerado como restritivo à liberdade dos Estados signatários.

O termo "compulsório" é revestido, de certa forma, por um significado pejorativo, se considerarmos que tudo o que é compulsório significa uma imposição ou restrição à liberdade de optar, por não fazer determinada coisa ou agir de determinada maneira; mas dada a possibilidade de escolha estabelecida pela própria Convenção, podemos entender que não há imposição, mas sim possibilidade. A obrigatoriedade das provisões contidas na Parte XV é tida por Boyle como o "cimento que mantém a estrutura unida para assegurar que será interpretada e aplicada de forma consistente". ${ }^{54}$

Outro ponto fraco a ser considerado são as inúmeras imposições e requisitos procedimentais que acabam por limitar sua atuação, o que é considerado por Colson e Hoyle ${ }^{55}$ como uma forma de evitar a proferição de decisões obrigatórias. Antes de referir um caso ao Tribunal, o requerente deve preencher o requisito contido no art. 286, comprovando que os meios de resolução contidos na seção 1 da Parte XV foram infrutíferos, os denominados meios pacíficos de solução de conflitos (negociação, mediação, arbitragem, conciliação e acordo judicial).

Art. 286: Aplicação dos procedimentos nos termos da presente seção

Salvo o disposto na seção 3, qualquer controvérsia relativa à interpretação ou aplicação da presente Convenção, quando não tiver sido solucionada mediante a aplicação da seção 1 , será submetida, a pedido de qualquer das partes na controvérsia, à corte ou tribunal que tenha jurisdição nos termos da presente seção.

Art. 287: Escolha do procedimento

${ }^{54}$ BOYLE, apud COLSON, David A.; HOYLE, Peggy. Satisfying the procedural prerequisites to the compulsory dispute settlement mechanisms of the 192 Law of the Sea Convention: Did the Southern Bluefin Tuna Tribunal Get it Right? 2009. p. 61. [...] was considered the cement to hold the structure together and to insure that it would be interpreted and applied consistently.

${ }^{55}$ Ibidem, p. 60. 
1. Um Estado ao assinar ou ratificar a presente Convenção ou a ela aderir, ou em qualquer momento ulterior, pode escolher livremente, por meio de declaração escrita, um ou mais dos seguintes meios para a solução das controvérsia relativas à interpretação ou aplicação da presente Convenção:

a) o Tribunal Internacional do Direito do Mar estabelecido de conformidade com o Anexo VI;

b) a Corte Internacional de Justiça;

c) um tribunal arbitral constituído de conformidade com o Anexo VII;

d) um tribunal arbitral especial constituído de conformidade com o Anexo VIII, para uma ou mais das categorias de controvérsias especificadas no referido Anexo.

2. Uma declaração feita nos termos do parágrafo $1^{\circ}$ não deve afetar a obrigação de um Estado Parte de aceitar, na medida e na forma estabelecidas na seção 5 da Parte XI, a competência da Câmara de Controvérsias dos Fundos Marinhos do Tribunal Internacional do Direito do Mar nem deve ser afetada por essa obrigação.

3. O Estado Parte que é parte numa controvérsia não abrangida por uma declaração vigente, deve ser considerado como tendo aceitado a arbitragem, de conformidade com o Anexo VII.

4. Se as partes numa controvérsia tiverem aceitado o mesmo procedimento para a solução da controvérsia, esta só poderá ser submetida a esse procedimento, salvo acordo em contrário das partes.

5. Se as partes numa controvérsia não tiverem aceitado o mesmo procedimento para a solução da controvérsia, esta só poderá ser submetida a arbitragem, de conformidade com o Anexo VII, salvo acordo em contrário das partes.

6. Uma declaração feita nos termos do parágrafo $1^{\circ}$ manter-se-á em vigor até três meses depois da notificação de revogação ter sido depositada junto do Secretário Geral das Nações Unidas.

7. Nenhuma nova declaração, notificação de revogação ou expiração de uma declaração afeta de modo algum os procedimentos pendentes numa corte ou tribunal que tenha jurisdição nos termos do presente artigo, salvo acordo em contrário das partes.

8. As declarações e notificações referidas no presente artigo serão depositadas junto do Secretário Geral das Nações Unidas, que deve remeter cópias das mesmas aos Estados Partes.

Por meio dessas imposições, a parte deve estar preparada para comprovar que é elegível para invocar os procedimentos contidos na Seção 2, sendo a disputa acerca da interpretação da Convenção; as partes não chegaram a um acordo; as partes não são parte de um acordo bilateral,

regional ou geral acerca do assunto e; as partes não entra- ram em outro procedimento para a resolução desse conflito. Essa dificuldade de as partes conseguirem preencher os requisitos contidos na Seção 1 pode ser observada em dois casos: o Caso Southern Bluefin Tuna e o Caso MOX Plant, que serão analisados em capítulo à parte.

Em ambos os casos, os requeridos contestaram a competência do Tribunal alegando que não foram preenchidos os requisitos anteriormente citados, tendo o Tribunal rejeitado sua competência no primeiro caso e aceitando-a no segundo. Colson e Hoyle propõem que, para que um Estado consiga acessar a jurisdição compulsória do Tribunal, algumas medidas devem ser tomadas: (a) fazer um registro de todos os acordos em que as partes envolvidas na disputa são participantes, para que a disputa seja diferenciada perante a Convenção, e para demonstrar que os acordos e convenções complementares não são uma alternativa à resolução do conflito em questão e; (b) o requerente deve considerar se houve realmente uma troca de ideias com a outra parte envolvida a respeito das prováveis soluções. ${ }^{56}$

Obviamente não há um período de tempo estabelecido para que essas discussões prévias sejam conduzidas. $\mathrm{O}$ que, sob o ponto de vista desses dois autores, é de suma importância, é conduzir as discussões de forma significativa e sob a Convenção. Esses dois fatores sobrepõem a duração da discussão, colocando mais uma vez o conhecimento popular de que a qualidade é melhor que a quantidade, sendo que o excelentíssimo juiz Tullio Treves afirma que o artigo 282 serve para reafirmar a liberdade que os Estados têm de escolher os meios para solucionar suas controvérsias. ${ }^{57}$

Devido à grande importância dada ao Tribunal Internacional para o Direito do Mar pela comunidade internacional, é necessário que determinados procedimentos sejam revistos para facilitar o acesso a ele, ainda mais em um contexto onde os Estados levam cada vez menos a sério suas obrigações de proteção ao ambiente marinho. Um tribunal especializado como esse deve possuir instrumentos que evitem o forum shopping em casos em que haja competências concorrentes, como nos casos analisados a seguir, tornando-se uma instituição confiável e aumentando sua utilização em conflitos envolvendo a matéria do Direito do Mar.

\footnotetext{
${ }^{56}$ BOYLE, apud COLSON, David A.; HOYLE, Peggy. Satisfying the procedural prerequisites to the compulsory dispute settlement mechanisms of the 192 Law of the Sea Convention: Did the Southern Bluefin Tuna Tribunal Get it Right? 2009. p. 75.

${ }^{57}$ Ibidem, p. 73.
} 


\section{O caso southern bluefin tuna e 0 caso Mox Plant - formação de precedentes}

Em 1993 foi formada uma convenção regional entre Japão, Austrália e Nova Zelândia para a conservação de uma espécie de atum comum na região (Convention for the Conservation of the Southern Bluefin Tuna-CCSBT), convencionando-se uma quantidade desse peixe que cada uma das partes poderia explorar. Em meados de 1998, houve uma dificuldade em estabelecer essas quotas, sendo que se continuou a aplicar a quota estabelecida em 1994. Nesse mesmo período, apesar de a Nova Zelândia e a Austrália terem se manifestado contra, o Japão estipulou unilateralmente um programa de pesca experimental que duraria aproximadamente três anos.

Em resposta a essa atitude unilateral, os dois outros Estados requereram oficialmente que consultas formais fossem executadas a respeito das provisões acerca da solução de controvérsias da CCSBT, a qual estipula diversas formas de solução de controvérsias pacíficas, não sendo permitida a iniciação unilateral de um procedimento compulsório. As negociações foram intensas e infrutíferas, tendo o Japão levantado a possibilidade de remeter o caso à mediação, proposição posteriormente rejeitada, porque a Austrália impôs o término do programa de pesca experimental, o que foi rejeitado pelo Japão.

Com a rejeição do Japão, a Austrália notificou as autoridades governamentais que remeteria o caso ao Tribunal Internacional para o Direito do Mar, sob a Parte XV da Convenção, dando início aos procedimentos compulsórios. Os três Estados- Partes nessa lide são signatários da Convenção, e não manifestaram contrariedade à adoção do foro do Tribunal. A Austrália e a Nova Zelândia requereram perante o Tribunal a emissão de uma medida provisória nos termos do artigo $290(5)^{58}$ da Convenção.

\footnotetext{
${ }^{58}$ Art. 290 (5): Enquanto não estiver constituído o tribunal arbitral ao qual uma controvérsia esteja a ser submetida nos termos da presente seção, qualquer corte ou tribunal, escolhido de comum acordo pelas partes ou, na falta de tal acordo, dentro de duas semanas subseqüentes à data do pedido de medidas provisórias, o Tribunal Internacional do Direito do Mar, ou, tratando-se de atividades na Área, a Câmara de Controvérsias dos Fundos Marinhos, pode decretar, modificar ou revogar medidas provisórias nos termos do presente artigo, se considerar, prima facie, que o tribunal a ser constituído teria jurisdição e que a urgência da situação assim o requer. Logo que estiver constituído, o tribunal ao qual a controvérsia foi submetida pode, atuando de conformidade com os parágrafos $1^{\circ} \mathrm{a} 4^{\circ}$, modificar, revogar ou confirmar essas medidas provisórias.
}

O Japão imediatamente colocou-se contra a competência do Tribunal, valendo-se de dois argumentos: (a) a questão não se tratava de problemas de interpretação ou aplicação da Convenção, mas sim da CCSBT e; (b) a Austrália e a Nova Zelândia não haviam esgotado as possibilidade de composição amigáveis da questão. O Tribunal rejeitou os argumentos levantados, afirmando que o fato de a CCSBT também ser aplicável ao caso não exclui sua competência, e também que as negociações e consultas haviam sido feitas entre as partes, tendo sido esgotadas.

Como consequência, em 27 de Agosto de 1999 o Tribunal decidiu que tinha competência para solucionar a disputa, prescrevendo uma série de medidas provisórias, e remetendo ao caso para o anexo VII (Arbitragem). Apesar de o Tribunal ter decidido ter competência para lidar com a questão, o Japão continuou mostrando-se contrário à situação, levantando os mesmo argumentos trazidos anteriormente.

O tribunal arbitral entendeu que os meios pacíficos de resolução da lide tinham sido esgotados, apesar de não terem sido utilizados todos os meios especificados no artigo da CCSBT sobre a matéria, concluindo que as partes não tinham obrigação de negociar indefinidamente, por fim, afirmando terem sido preenchidos os requisitos presentes no artigo $281(1)^{59}$ da Convenção. Por fim, ao contrário do que todos imaginavam, o tribunal arbitral decidiu que essa questão surgiu sob o âmbito das duas convenções e por isso, quem deveria ter competência para dirimir o conflito é a CCSBT.

O Caso MOX Plant é considerado por Colson e Hoyle como um teste ao precedente formado no caso Southern Bluefin Tuna. Esse caso foi iniciado em 25 de outubro de 2001, depois que uma notificação feita pela Irlanda, pedindo que um tribunal arbitral fosse convocado sob a alegação de que o Reino Unido violou disposições da Convenção ao autorizar a construção da planta MOX de energia nuclear em Sellafield, Cumbria.

\footnotetext{
${ }^{59}$ Art. 281 (1): Se os Estados-Partes que são partes numa controvérsia relativa à interpretação ou aplicação da presente Convenção tiverem acordado em procurar solucioná-la por um meio pacífico de sua própria escolha, os procedimentos estabelecidos na presente Parte só serão aplicados se não tiver sido alcançada uma solução por esse meio e se o acordo entre as partes não excluir a possibilidade de outro procedimento.
} 
Ambos os países são signatários da Convenção, mas não optaram pela mesma forma de solução de conflitos, sendo remetidos obrigatoriamente ao Anexo XV dela. Da mesma forma ocorrida no caso Southern Bluefin Tuna, a Irlanda se valeu do artigo 290 para requerer a emissão de medidas provisórias pelo Tribunal para que a construção da planta fosse suspensa, ou para diminuir os efeitos que seriam causados se ela fosse construída.

O Reino Unido respondeu que a Convenção não poderia impor tais medidas porque o tribunal arbitral a ser constituído não teria competência sobre a disputa, levantando que a Irlanda também não tinha sido capaz de completar os requisitos presentes no artigo $282^{60}$ da Seção 1 da Convenção. O principal argumento foi que a questão era regida por acordos regionais com seus próprios mecanismos obrigatórios de resolução de controvérsias, adicionando o fato de que o requisito de se realizar consultas e discussões acerca da matéria, previsto no artigo $293^{61}$, também não tinha sido preenchido, visto que a Irlanda havia negado seu pedido.

A Irlanda contra-argumentou afirmando que o presente caso se tratava de uma questão de interpretação da Convenção, e não dos acordos regionais de que as partes eram signatárias, sendo elas complementares à Convenção sobre o Direito do Mar. Com relação ao segundo argumento levantado pelo Reino Unido, a Irlanda alegou ter enviado uma carta alguns meses antes do começo dos procedimentos arbitrais, sendo que eles somente foram requisitados após o Reino Unido ter se negado a suspender a autorização para a construção da planta.

Após analisar os argumentos levantados pelas partes, o Tribunal decidiu ter competência para resolver a

${ }^{60}$ Art. 282: Obrigações decorrentes de acordos gerais, regionais ou bilaterais. Se os Estados Partes que são partes numa controvérsia relativa à interpretação ou aplicação da presente Convenção tiverem ajustado, por meio de acordo geral, regional ou bilateral, ou de qualquer outra forma, em que tal controvérsia seja submetida, a pedido de qualquer das partes na mesma, a um procedimento conducente a uma decisão obrigatória, esse procedimento será aplicado em lugar do previsto na presente Parte, salvo acordo em contrário das partes na controvérsia.

${ }^{61}$ Art. 293: Direito aplicável

1. A corte ou tribunal que tiver jurisdição nos termos desta seção deve aplicar a presente Convenção e outras normas de direito internacional que não forem incompatíveis com esta Convenção.

2. O parágrafo $1^{\circ}$ não prejudicará a faculdade da corte ou tribunal que tiver jurisdição nos termos da presente seção de decidir um caso ex aequo et bono, se as partes assim o acordarem. questão, contrariando o precedente formado pelo caso Southern Bluefin Tuna. Ele considerou a questão como envolvendo a Convenção, somente, deixando de lado os acordos regionais, interpretando o artigo 282 restritivamente, o que não foi feito no caso anterior, tendo o tribunal considerado a questão como igual sob as duas convenções.

Além disso, o tribunal desconsiderou as alegações do Reino Unido, pois concluiu que nenhuma das partes tem a obrigação de discutir uma questão indefinidamente quando acha que todas as possibilidades de se chegar a um acordo foram exauridas. A interpretação extensiva do artigo 282 poderia impor barreiras à liberdade de escolha dos Estados.

Contrariamente ao caso Southern Bluefin Tuna, o tribunal excluiu os outros acordos regionais, considerando o caso como sendo de aplicação da Convenção, tornando a decisão um meio atrativo de desviar as armadilhas criadas pela decisão proferida, nas palavras de Colson e Hoyle. A conclusão que podemos tirar é que não há um consenso na aplicação da Convenção, até mesmo por aqueles que a escreveram e negociaram, levando em consideração que grande parte dos juízes que compõe o Tribunal àquela época era composta pelos mesmos juristas que fizeram parte dos primórdios da Convenção de Montego Bay de 1982.

Como já arguido anteriormente, há a necessidade de realizar uma revisão dessas disposições a respeito dos requisitos a serem preenchidos, para que elas não se tornem barreiras ao acesso dos Estados ao Tribunal, mas sim se tornem uma forma de proteção ao direito de escolha deles, diminuindo a resistência de Estados e autores contrários à manutenção de um tribunal especializado, como é o Tribunal Internacional para o Direito do Mar.

\section{Considerações finais}

Apesar de representar um grande avanço em matéria de formação de jurisprudência no âmbito do Direito do Mar, o Tribunal Internacional para o Direito do Mar ainda tem uma ação muito limitada no que concerne às exceções que podem ser estabelecidas a partir do Artigo 298 da Convenção.

O Tribunal tem, como outro tribunal qualquer, limitações quanto a sua jurisdição e, apesar do número 
limitado de casos referidos a ele, foi capaz de contribuir tanto para o desenvolvimento do Direito do Mar, quanto para o Direito Internacional de uma forma geral, preenchendo um vácuo há muito tempo existente.

Também é possível concluir que os pareceres consultivos são uma alternativa muito utilizada pelos Estados e outras partes para a resolução de conflitos, principalmente por não possuírem caráter obrigatório para as partes envolvidas e, consequentemente, não as colocarem em riscos judiciais.

O poder dado ao Tribunal de emitir medidas provisórias tem sido de suma importância para o desenvolvimento do Direito Internacional e do Direito do Mar, principalmente pelo fato de suas medidas provisórias poderem ser requeridas não apenas para proteger o direito das partes, bem como o ambiente marinho de riscos iminentes.

Com os casos Southern Bluefin Tuna e MOX Plant, fica claro que ainda há alguns pontos que devem ser corrigidos com relação à competência e o acesso ao Tribunal, sendo que há artigos que devem ser revistos para que não sejam impostas tantas barreiras aos Estados que optaram por seu foro, aumentando sua utilização e sua contribuição para a formação de jurisprudência, contribuindo também para estabelecer o papel do Tribunal como uma instituição especializada e necessária para o desenvolvimento do Direito Internacional.

\section{Referências}

ANAND, Ram Prakash. Law of the Sea: Caracas and Beyond. Haia: Martinus Nijhoff Publishers, 1980.

BENDER, Philip. Current Legal Developments International Tribunal for the Law of the Sea: The Tomimaru and Hoshinmaru Cases before ITLOS. The International Journal of Maritime and Coastal Law, Martinus Nijhoff Publishers, n. 23, p. 349-358, 2008.

BRASIL. Decreto n. 1.530, de 22 de junho de 1995. Declara a entrada em vigor da Convenção das Nações Unidas sobre o Direito do Mar, concluída em Montego Bay, Jamaica, em 10 de Dezembro de 1982. Disponível em: <http://www2.mre.gov.br/dai/m_1530_1995.htm>. Acesso em: 27 set. 2011.

CALIXTO, Robson José. Incidentes marítimos: história, direito marítimo e perspectivas num mundo em Reforma da Ordem Internacional. São Paulo: Aduaneiras, 2004.
CASELLA, Paulo Borba. Direito internacional dos espaços. São Paulo: Atlas, 2009.

COLSON, David A.; HOYLE, Peggy. Satisfying the procedural prerequisites to the compulsory dispute settlement mechanisms of the 192 Law of the Sea Convention: Did the Southern Bluefin Tuna Tribunal Get it Right?. Ocean Development and International Law, Taylor Francis, Washington, n. 34, p. 59-82, 2009.

CHURCHILL, Robin. Dispute settlement under the UN Convention on the Law of the Sea: survey for 2008. The International Jurnal of Marine and Coastal Law, Martinus Nijhoff Publishers, v. 24, p. 603-616, 2009.

CHURCHILL, Robin. Dispute Settlement under the UN Convention on the Law of the Sea: Survey for 2009. International Journal of Marine and Coastal Law, Martinus Nijhoff Publishers, v. 25, p. 457-482, 2010.

GROVES, Steven. Accession to the U.N Convention o the Law of the Sea is Unecessary to Secure U.S. Navigational Rights and Freedoms. The Heritage Foundation, Backgrounder, Washington, n. 2599, 2011. Disponível em: <http://report.heritage.org/bg2599>. Acesso em: 28 ago. 2011.

KEYUAN, Zou. The International Tribunal for the Law of the Sea: Procedures, Practices, and Asian States. Ocean Developmend and International Law, Taylor and Francis Group, 41, 131-151, 2010.

KLEIN, Natalie. Maritime Security and the Law of the Sea. Nova Iorque: Oxford University Press, 2011.

MATTOS, Adherbal Meira. O novo Direito do Mar. Rio de Janeiro: Renovar, 2008.

MENSAH, Thomas A. Provisional Measures in the International Tribunal for the Law of the Sea (ITLOS). Max-Planck-Institut für ausländisches öffentliches Recht und Volkrecht, 2002. Disponível em: <http://www.zaoerv. de/62_2002/62_2002_1_a_43_54.pdf $>$. Acesso em: 27 set. 2011

MIRANDA, Jorge. Curso de direito internacional público. 3. ed. Estoril: Princípia, 2006.

NDIAYE, Tafsir Malick. The advisory function of the International Tribunal for the Law of the Sea. Chinese Journal of International Law, Oxford, Oxford University Press, n. 9, p. 565-587, 2010.

PEREIRA, André Gonçalves; QUADROS, Fausto de. Manual de direito internacional público. 3. ed. Coimbra: Almedina, 2005. 
SEYMOUR, Jillaine. The International Tribunal for the Law of the Sea: A great Mistake? Indiana Journal of Global Studies. Indiana: Indiana University Press, 2005.

UNCLOS - UNITED Nations Convention on the Law of the Seas. Montego Bay, 10 December 1982. Disponível em: <http://www.admiraltylawguide.com/conven/unclos table.html>.Acesso em: 12 mai. 2010.
VARELLA, Marcelo Dias. Direito internacional público. Brasília: UniCEUB, 2008.

VICUÑA, Francisco Orrego. The International Tribunal for The Law of the Sea and Provisional Measures: Settled Issues and Pending Problems. The International Journal of Maritime and Coastal Law, Koninklijke Brill NV, v.22, n.3, p. 451-462, 2007. 